\title{
Lean and agile in small- and medium-sized enterprises: Complementary or incompatible?
}

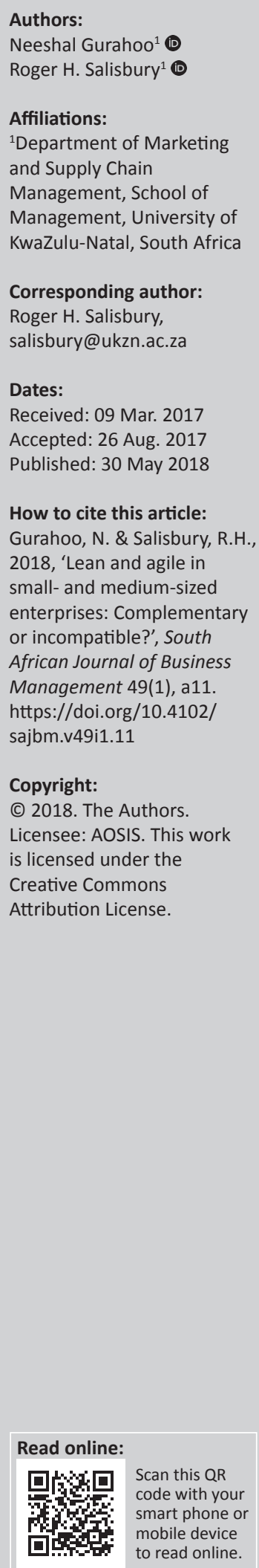

Background: This study explores the relationship between the implementation of lean supply chain management and the agility of manufacturing small- and medium-sized enterprises (SMEs). Although some studies have suggested that these two approaches are mutually exclusive, other research finds that they may be applied to different parts of the supply chain or may be compatible through the common elements of process integration and supply chainwide collaboration.

Objectives: Through an investigation of two companies at different stages of lean implementation, this study sought to establish which of these paradigms might be applicable in the context of South African SMEs.

Method: Semi-structured interviews were conducted with managers at both companies, and the progress towards lean manufacturing was probed.

Results: Company B was found to have made considerably more progress towards a lean system than Company A. Neither company had achieved just-in-time purchasing, and this was identified as a challenging aspect for SMEs. Both companies experienced stockouts and long lead times. The volatile nature of their markets indicated a need for greater agility. Company B was found to have a greater potential for speed, flexibility and response. It is proposed that this may be a direct consequence of greater progress in lean implementation.

Conclusion: It was concluded that strategies to implement lean are a necessary prelude to achieving an agile enterprise. This article presents a model incorporating the lean principles that SMEs should adopt in order to achieve agility.

\section{Introduction}

There has been considerable interest in the potential for strategies such as lean supply chain management and agility to contribute to increased efficiency and profitability of South African manufacturing firms. Although lean is well established and components including six sigma, total quality management (TQM) and just-in-time (JIT) are widely known in local industry, agility is a more recent concept. Furthermore, the relationship between lean and agile is not clear, and there is considerable disagreement in the literature as to whether these two strategies are mutually supportive or mutually exclusive.

Small- and medium-sized enterprises (SMEs) form a crucial part of emerging economies (Abor \& Quartey 2010:218), and these businesses can also benefit from the implementation of lean ideas. In a rapidly changing marketplace, SMEs may also need to display agility to meet changing customer expectations.

This study sought to develop a framework within which to investigate the implementation of lean in South African SMEs and to discover whether lean implementation in SMEs is associated with improved or compromised agility by assessing if leaner organisations are better or worse placed to respond to volatile demand.

\section{Literature review}

Lean had its origins in the Toyota Production System which was developed in the mid-20th century as an alternative to mass production in the automotive industry (Womack, Jones \& Roos 1990). The concept of the Agile Enterprise was introduced by the Iacocca Institute at Lehigh University in 1991 to provide 21st century manufacturers with a strategy to address volatile markets (Naylor, Naim \& Berry 1999:107; Purvis, Gosling \& Naim 2014:107). 


\section{Lean principles}

The fundamental principles of lean are the reduction of waste and the development of a production process that operates on a pull force from the customer (Womack \& Jones 2003:24). For Toyota, this approach to manufacturing allowed them to reduce their cost of production and to develop markets both within Japan and internationally.

Lean literature often cites seven wastes to be eliminated. These are muda of manpower, production, inventories, excess processing, defects, waiting, transport and facilities (Dahlgaard \& Dahlgaard-Park 2006:264). Early literature suggested that this could be achieved through JIT, autonomation, a flexible workforce and capitalising on worker suggestions (Monden 1983:2).

Shah and Ward (2003:129) divided lean operational practices into four 'bundles': JIT, TQM, total preventive maintenance (TPM) and human resource management (HRM). Their study was concerned with operational performance relating to lean practices, but JIT has a strong element of supplier management, while TQM is based on the idea that quality is defined by the customer. Some authors are particularly concerned with lean supply networks (e.g. Bortolotti et al. 2016; Lamming 2005) or lean distribution (Reichhart \& Holweg 2007); but in their landmark work, The Machine that Changed the World, Womack et al. (1990) emphasised that lean is a supply chain-wide concept, encompassing suppliers and customers. This conceptualisation of the linkages between the four themes and the elimination of the seven wastes of lean is depicted in Figure 1. This study follows this approach and identifies lean practices under four broad themes: supplier management, operational practices, personnel and customer relations. Although the first and

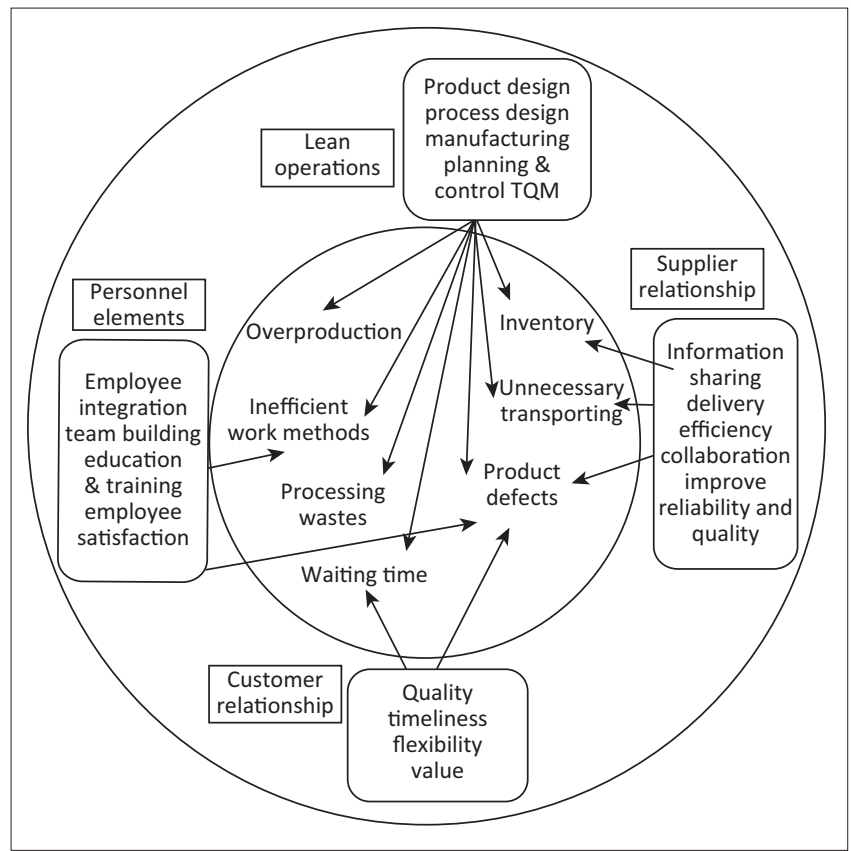

TQM, total quality management.

FIGURE 1: Four themes of lean supply chain management and their influence on the seven wastes of lean. last are concerned with stakeholders external to the focus company of the supply chain, the other two are concerned with the two broad aspects of lean operations: machines and people.

\section{Agile capabilities}

Christopher (2000:37) described agility as a business approach that has flexibility as its fundamental principle. This enables a manufacturer to respond rapidly to changes in the volume and variety of goods required by the market.

In order to develop agile capability, a firm needs to develop a supply chain that is focussed on the customer and that exhibits cooperation between stakeholders and effectively deploys people and information to manage uncertainty (van Hoek, Harrison \& Christopher 2001:129). These authors developed a framework to assess agility in supply chains. The four key characteristics of an agile supply chain that they identified were customer sensitivity, virtual integration, process integration and network integration. Some key strategies of agile supply chains which are identified by Yusuf et al. (2014:552) are the virtual supply chain, a knowledgeable workforce and enterprise planning systems.

Various authors have identified agile enablers that facilitate the development of agility in an organisation. These are summarised in Table 1. The consensus seems to be that technology plays a vital role in facilitating better communication between stakeholders. Customers become involved in product design, as do suppliers. Employees are empowered and self-managed, and the hierarchy of the organisation is flattened.

TABLE 1: Factors facilitating agility in various aspects of the supply chain.

\begin{tabular}{|c|c|c|}
\hline Supply chain aspect & Agility enabler & Example of source \\
\hline $\begin{array}{l}\text { A. Supplier } \\
\text { relationships }\end{array}$ & $\begin{array}{l}\text { 1. VMI } \\
\text { 2. Information sharing (e.g. } \\
\text { point-of-sale information, } \\
\text { electronic data interchange } \\
\text { and collaborative planning, } \\
\text { forecasting and } \\
\text { replenishment) } \\
\text { 3. Strategic partnering } \\
\text { 4. Product, volume and mix } \\
\text { flexibility } \\
\text { 5. Alliances } \\
\text { 6. Virtual enterprise }\end{array}$ & $\begin{array}{l}\text { 1. Power, Sohal and Rahman } \\
\text { (2001:252) } \\
\text { 2. Yusuf, Sarhadi and } \\
\text { Gunasekaran (1999:39); } \\
\text { Pandey and Garg (2009:101) } \\
\text { 3. Cao and Dowlatshahi } \\
\text { (2005:534) } \\
\text { 4. Bottani (2010:253) } \\
\text { 5. Gunasekaran and Yusuf } \\
\text { (2002:1363) } \\
\text { 6. Yusuf et al. (2014:552); Cao } \\
\text { and Dowlatshahi (2005:534) }\end{array}$ \\
\hline B. Operations & $\begin{array}{l}\text { 1. Technology } \\
\text { 2. Enterprise resource } \\
\text { planning } \\
\text { 3. Robotics }\end{array}$ & $\begin{array}{l}\text { 1. Power et al. (2001:251) } \\
\text { 2. Gunasekaran and Yusuf } \\
\text { (2002:1363) } \\
\text { 3. Gunasekaran and Yusuf } \\
(2002: 1370)\end{array}$ \\
\hline $\begin{array}{l}\text { C. Organisational } \\
\text { culture and } \\
\text { personnel }\end{array}$ & $\begin{array}{l}\text { 1. Focus on core competence } \\
\text { 2. Trust information available } \\
\text { 3. Employee empowerment } \\
\text { 4. Participative management } \\
\text { style } \\
\text { 5. Self-managed teams } \\
\text { 6. Innovation } \\
\text { 7. Continuous improvement }\end{array}$ & $\begin{array}{l}\text { 1. Yusuf et al. (1999:38) } \\
\text { 2. Bottani (2010:253) } \\
\text { 3. Gunasekaran (1999:97) } \\
\text { 4. Power et al. (2001:251) } \\
\text { 5. Gunasekaran and Yusuf } \\
\text { (2002:1365) } \\
\text { 6. Duguay, Landry and Pasin } \\
\text { (1997:1190); Power et al. } \\
\text { (2001:252) }\end{array}$ \\
\hline $\begin{array}{l}\text { D. Customer } \\
\text { relations }\end{array}$ & $\begin{array}{l}\text { 1. Delivery lead time } \\
\text { 2. Product quality } \\
\text { 3. After-sales service } \\
\text { 4. Customer satisfaction }\end{array}$ & $\begin{array}{l}\text { 1. Bottani (2010:253) } \\
\text { 2. Bottani (2010:253) } \\
\text { 3. Gunasekaran (1999:91) } \\
\text { 4. Zhang (2011:306) }\end{array}$ \\
\hline
\end{tabular}

VMI, vendor managed inventory. 


\section{Lean versus agile manufacturing}

Some essential differences between the lean and agile approaches have been proposed. Christopher (2000:38) described lean as suitable for products with low variety and high volume and defined agility as the ability to respond to changes in volume and variety of demand. Nel and Badenhorst-Weiss (2012:191) contended that firms must make a trade-off between responsiveness (agility) and efficiency (leanness) depending on the nature of their markets. They asserted that lean requires predictable demand and is suitable for a low-cost strategy, while agility is appropriate where high service levels are required by the market. This is consistent with earlier work by Mason-Jones, Naylor and Towill (2000:1064) that identified service level as the market winner for fashion goods with a volatile market and price as the market winner for commodities, which have a steady demand. Thus, the nature of the product determines the appropriate strategy for the firm producing it. Naylor et al. (1999:109) identified robustness and the need for stable demand as the two key areas where lean and agile differ. They saw these as being in conflict, with a system designed to meet a stable demand (lean) lacking the robust capacity to respond to variations and disturbances in the market (agile). Purvis et al. (2014:100) proposed that the level and type of flexibility required differentiate between lean and agile supply chains.

The authors cited above suggested that lean and agile are mutually exclusive in the same region of the supply chain and at the same time. Proponents of a 'leagile' strategy propose that a decoupling point may separate two parts of the supply chain: a lean section upstream and an agile section downstream of this point (Mason-Jones et al. 2000:4065). Agile production is order-driven and accommodates highly variable demand for a wide variety of products. Lean is forecast driven with smoothed demand and reduced variety. This implies that most product differentiation occurs after the decoupling point. Stock is held at the decoupling point to allow both strategies to operate effectively (Naylor et al. 1999:114). This strategy does not contemplate superimposing agile on lean.

In spite of differences in emphasis between flexibility (agile) and level scheduling (lean), common characteristics of the two approaches may be identified (Naylor et al. 1999:110). Both approaches require process integration and collaboration across the supply chain (Christopher \& Towill 2000:208; Womack \& Jones 2003:24). The elimination of waste is desirable in agile systems as well as lean, and the rapid reconfiguration required for a quick response to changing markets also increases efficiency for lean production (Naylor et al. 1999:111). Gunasekaran, McGaughey and Wolstencroft (2001:25) preferred to view agility as a management philosophy that uses tools, which may include flexible manufacturing, lean production and computer-integrated manufacturing, in order to achieve the goal of producing both volume and variety. These authors did not see lean and agile as incompatible.
In their analysis of the evolution from mass production through lean to agile manufacturing (AM), Jin-Hai, Anderson and Harrison (2003:178) saw lean as the successor to mass production and the precursor of agile. It must be noted that their understanding of lean was in its narrow sense which involves only the factory floor. Hence, when they introduced the concept of real agile manufacturing (RAM), a differentiating feature was that it crosses organisational boundaries. This is also a fundamental idea of the strategic alliances built in lean (Womack \& Jones 2003:277) and hence not a revolutionary idea when moving to AM. Inman et al. (2011:346) took a broader view of lean and investigated the relationship between its key element, JIT and agility. They found that JIT-purchasing supported agility but that JITproduction was not a precursor of agility. However, they did not find that JIT (and by implication, lean) and agile were mutually exclusive. They suggested that in firms which already exhibit manufacturing excellence, greater agility can be achieved principally through further supply chain integration as evidenced by greater levels of JIT-purchasing. This supports the idea that agility exists as an extension beyond lean but is fully compatible with fundamental lean principles. Yusuf et al. (2014:532) went as far as to assert that 'agility is built on leanness'.

The truly lean organisation in a lean supply chain may therefore already have in place many of the key competencies which position it to move further into an agile paradigm. Alternatively, lean organisations may lack agility because of inflexible operating practices.

\section{Leanness and agility for small- and medium-sized enterprises}

Lean thinking has permeated large-scale manufacturing in the developed world and has been successful in developing countries like India, particularly in the large-scale automotive and electronics industries (Panizzolo et al. 2012:771). Similarly, agile ideas have gained traction since the beginning of the 21st century (Naim \& Gosling 2011:342). However, the literature suggests that lean implementation in SMEs has been slower (Hu et al. 2015:981). These authors found that the majority of studies of lean in SMEs took place in developed countries, and of the $28 \%$ which were studied in developing countries, the overwhelming majority were of SMEs in India. African SMEs were not featured.

Dahlgaard and Dahlgaard-Park (2006:266) noted that the basic principles of lean production are those of craft industries: the focus on delivering value to the customer and pursuing perfection predated the Industrial Revolution and should be achievable in small businesses and in less sophisticated markets. Chong, Chin and Loh (2013) suggested that lean implementation in SMEs is hampered by a focus on short-term benefits; but these authors also suggested that the smaller workforce, less complicated products and simpler organisational structure of SMEs make them ideal candidates for lean. Small- and medium-sized enterprises are well placed to achieve the agile goal of producing small batch 
sizes or even batch sizes of one provided they are placed within a collaborative network which allows coordination of activities among SMEs and demand information flow (Fornasiero \& Zangiacomi 2013:2111).

Despite the challenges associated with implementing lean and agile in SMEs, they will also benefit from reductions in waste and increased responsiveness to changing markets. Fening, Pesakovic and Amaria (2008) investigated the effect of quality management, an important component of lean, on SME performance in Ghana. They found that the performance of these businesses was improved in terms of profitability and employee satisfaction. Achanga et al. (2006:467) described the key success factors for the introduction of lean in SMEs as leadership management, financial capabilities, skills and expertise, and organisational culture.

Hu et al. (2015:984) noted that it is important to define the scope when discussing lean, as this may range from changes made only at the operational level to a complete change in philosophy for the entire supply chain. Small- and mediumsized enterprises may find themselves lacking the influence needed to bring about supply chain-wide changes. A more limited definition of lean, which focusses on operations management, was found to be the one most often implemented in SMEs. These authors pointed out that the strategic implementation of lean at the SME supply chain level is not well understood.

Chung and Chan (2001:601) suggested that SMEs will need to use information technology (IT) to facilitate the development of alliances and networks which will allow them to develop agile strategies.

In spite of the limited literature available on agility in SMEs, those that have implemented lean may look to this strategy as a way to increase profitability or simply to remain viable in a volatile marketplace. Two companies at different stages of implementing lean and whose management was contemplating the need for agility were the subject of this study.

\section{Methodology}

This study was exploratory in nature because there is little published about leanness and agility for SMEs, particularly in developing countries, and the goal is therefore to develop theory that is appropriate to this context (Ketokivi \& Choi 2014:234). A comparative case study approach was used as described in Yin (2003:14), but restricted to a convenience sample of two Pietermaritzburg SMEs so that these companies could be studied in depth. These companies were selected on their implementation of lean and interest in agility.

Qualitative data were collected using semi-structured interviews with company managers (Bruce, Daly \& Towers 2004:157). An interview guide was developed to probe the operational practices of the two organisations (Boyce \& Neale 2006:3). This interview guide probed the strategy and environment of the company, as well as the flow of information through the supply chain.

This broad investigation was followed by questions that were specifically designed to assess the level of implementation of lean. Waste reduction and JIT practices in the operations were closely investigated and supplier relationships were probed. The companies' relationship with customers and their logistics systems were assessed. Respondents were asked to describe the companies' organisational cultures.

These responses were categorised into four themes which contribute to lean waste reduction: Lean and JIT operations practices, supplier relationship management (SRM), customer relations, and organisational culture and personnel. The interview transcripts were analysed using codes developed from the literature. Particular words or phrases were identified as codes which expressed the fundamental ideas of the lean categories or themes and which would allow the researcher to identify whether the company performed poorly or well on these aspects.

The ideas in each of these themes which guided the selection of codes for analysis are summarised in Table 2.

Finally, the perceived need for agility was probed in the interviews. The companies' potential for implementation of this strategy was investigated using these data as well as

TABLE 2: Ideas guiding the selection of codes for each theme.

\begin{tabular}{|c|c|c|c|}
\hline $\begin{array}{l}\text { Lean and JIT } \\
\text { operations }\end{array}$ & Supplier & Customer & Personnel \\
\hline $\begin{array}{l}\text { Product design: } \\
\text { - Standardised } \\
\text { parts } \\
\text { - Modular design } \\
\text { - Quality } \\
\text { - Concurrent } \\
\text { engineering } \\
\text { - PLM }\end{array}$ & $\begin{array}{l}\text { Information sharing } \\
\text { with suppliers: } \\
\text { - Reduced } \\
\text { transaction } \\
\text { processing } \\
\text { - POS information } \\
\text { - Computer- } \\
\text { assisted ordering }\end{array}$ & $\begin{array}{l}\text { Quality: } \\
\text { - Management of } \\
\text { returns } \\
\text { - Communication } \\
\text { channels }\end{array}$ & $\begin{array}{l}\text { Employee } \\
\text { integration and } \\
\text { information flow: } \\
\text { - Problem solving } \\
\text { - Feedback to } \\
\text { employees } \\
\text { - Transparency }\end{array}$ \\
\hline $\begin{array}{l}\text { Process design: } \\
\text { - Small batches } \\
\text { - Reduced setup } \\
\text { time } \\
\text { - Work cells } \\
\text { - Fail safes } \\
\text { - Reduced } \\
\text { inventory }\end{array}$ & $\begin{array}{l}\text { Delivery efficiency: } \\
\text { - Frequent } \\
\text { deliveries to } \\
\text { Reduce inventory } \\
\text { - Small versus } \\
\text { large deliveries }\end{array}$ & $\begin{array}{l}\text { Timeliness: } \\
\text { - Order cycle time } \\
\text { waiting time } \\
\text { - Speed of delivery }\end{array}$ & $\begin{array}{l}\text { Team building: } \\
\text { - Motivation } \\
\text { - Cross-functional } \\
\text { - Job rotation }\end{array}$ \\
\hline $\begin{array}{l}\text { Manufacturing, } \\
\text { planning and } \\
\text { control: } \\
\text { - Visual systems } \\
\text { - Pull systems } \\
\text { - Level loading } \\
\text { and reduced } \\
\text { bottlenecks or } \\
\text { work-in-process } \\
\text { - Layout for } \\
\text { process flow } \\
\text { and flexibility }\end{array}$ & $\begin{array}{l}\text { Collaborative } \\
\text { relationships: } \\
\text { - Joint NPD } \\
\text { - Fewer suppliers } \\
\text { - Long-term } \\
\text { relationships }\end{array}$ & $\begin{array}{l}\text { Flexibility: } \\
\text { - Emergency order } \\
\text { procedures } \\
\text { - Choice of lot size } \\
\text { - Variety } \\
\text { - Customisation }\end{array}$ & $\begin{array}{l}\text { Learning } \\
\text { organisation: } \\
\text { - Continuous } \\
\text { improvement } \\
\text { - Change } \\
\text { management } \\
\text { - Training and } \\
\text { retraining }\end{array}$ \\
\hline $\begin{array}{l}\text { TQM: } \\
\text { - Continuous } \\
\text { improvement } \\
\text { - Six sigma } \\
\text { - TPM } \\
\text { - Housekeeping } \\
\text { (five S's) }\end{array}$ & $\begin{array}{l}\text { Improved quality } \\
\text { and reliability: } \\
\text { - Quality } \\
\text { inspection } \\
\text { - Supplier } \\
\text { responsiveness }\end{array}$ & $\begin{array}{l}\text { Value: } \\
\text { - Customer needs } \\
\text { assessment }\end{array}$ & $\begin{array}{l}\text { Employee welfare } \\
\text { and satisfaction: } \\
\text { - Disciplinary } \\
\text { action } \\
\text { - Health and safety } \\
\text { - Absenteeism } \\
\text { compensation } \\
\text { - Promotion } \\
\text { - Incentives }\end{array}$ \\
\hline
\end{tabular}

Note: Eliminating seven wastes of lean: Overproduction; Inventory; Unnecessary transporting; Inefficient work methods; Processing wastes; Waiting time; Product defects.

JIT, just-in-time; PLM, product life cycle management; NPD, new product development; TQM, total quality management; TPM, total productive maintenance. 
indicators of agile capability arising from the data collected on lean. Under each theme, an assessment was also made of its contribution to the agility or potential for progress towards an AM paradigm. Words implying speed, flexibility and response were identified as codes for this analysis.

Data were verified by observation of work activities and through the study of documentation provided by the companies.

The data collection process started with interviews with the CEO of each company followed by snowball sampling as each respondent recommended further candidates. A maximum of seven respondents from each company was interviewed but an effort was made to ensure that this included all relevant members of top management using a purposive sampling approach.

\section{Research findings}

The two companies are medium-sized manufacturing companies (400 - 500 employees) in KwaZulu-Natal. Company A manufactures electrical fittings using a plastic injection moulding process. Company B produces highspeed steel (HSS) cutting tools such as drill bits and reamers with two factories, one producing HSS tools and the other carbide tools.

The results of the lean assessment of the two companies are summarised below under the themes identified above.

\section{Supplier relations}

The performance of both companies with regard to lean supplier management is summarised in Table 3. Neither of the SMEs has been successful in introducing JIT supply, but

TABLE 3: Summary of lean supplier management performance of the two companies.

\begin{tabular}{|c|c|c|}
\hline Supplier & Company A & Company B \\
\hline \multicolumn{3}{|c|}{ Information sharing with suppliers } \\
\hline $\begin{array}{l}\text { 1. Reduced transaction } \\
\text { processing }\end{array}$ & $\begin{array}{l}\text { Yes - with local suppliers } \\
\text { No - international suppliers }\end{array}$ & $\begin{array}{l}\text { Yes-electronic } \\
\text { communication }\end{array}$ \\
\hline 2. Information sharing & No & Yes \\
\hline $\begin{array}{l}\text { 3. Computer-assisted } \\
\text { ordering }\end{array}$ & Yes - short processing times & Yes - MRP with Cispro \\
\hline \multicolumn{3}{|l|}{ Delivery efficiency } \\
\hline $\begin{array}{l}\text { 1. Frequent deliveries to } \\
\text { reduce inventory }\end{array}$ & $\begin{array}{l}\text { Yes - local suppliers } \\
\text { No - international suppliers }\end{array}$ & Yes \\
\hline $\begin{array}{l}\text { 2. Small versus large } \\
\text { deliveries }\end{array}$ & Large & Small \\
\hline \multicolumn{3}{|l|}{ Collaborative relationships } \\
\hline 1. Joint NPD & No & No \\
\hline 2. Fewer suppliers & No & No- $A B C$ classification \\
\hline 3. Long-term relationships & Yes - good communication & $\begin{array}{l}\text { Yes - especially raw } \\
\text { material suppliers }\end{array}$ \\
\hline 4. Outsourcing & No & Yes \\
\hline \multicolumn{3}{|c|}{ Improved quality and reliability } \\
\hline 1. Quality inspection & No & Yes \\
\hline 2. Supplier responsiveness & Average & $\begin{array}{l}\text { Good-local items } \\
\text { Poor-imported } \\
\text { materials, unexpected } \\
\text { delays common }\end{array}$ \\
\hline
\end{tabular}

NPD, new product development. both have progressed towards lean by reducing the size and increasing the frequency of delivery of supplies. Company A still has a transactional relationship with suppliers, apart from a few long-term suppliers. There was no evidence of lean practices such as outsourcing of non-core competencies or information sharing through IT. Company B has progressed to JIT supply with some local suppliers but still experiences unreliable supplies of imported materials. Ordering and communication with suppliers has been improved through IT, but there is as yet no evidence of collaborative new product development (NPD) or outsourcing.

\section{Lean and just-in-time operations}

The two companies are at different stages of lean implementation in their operations and this is reflected in their performance in lean and JIT operations management, which is summarised in Table 4.

Company A carries high levels of work-in-process inventory. It has long setup times and as a result produces large batches to avoid setting up a machine more than once a week. These are then transported to the assemblers which introduces further inefficiencies. High levels of finished goods inventories are held in an attempt to meet the demand but stockouts still occur.

TABLE 4: Summary of lean and just-in-time operations management performance.

\begin{tabular}{|c|c|c|}
\hline Lean and JIT operations & Company A & Company B \\
\hline \multicolumn{3}{|l|}{ Product design } \\
\hline 1. Standardised parts & Yes & No \\
\hline 2. Modular design & No & No \\
\hline 3. Quality & Yes & Yes \\
\hline 4. Concurrent engineering & No & Yes \\
\hline 5. PLM & No & No \\
\hline \multicolumn{3}{|l|}{ Process design } \\
\hline 1. Small batches & $\begin{array}{l}\text { No- long production runs } \\
\text { and continuous flow }\end{array}$ & Yes \\
\hline 2. Reduced setup time & $\mathrm{No}-3 \mathrm{~h}$ & $\begin{array}{l}\text { Yes }-10 \mathrm{~min} \text { (reduced } \\
\text { from } 2 \mathrm{~h} \text { ) }\end{array}$ \\
\hline 3. Work cells & No & $\begin{array}{l}\text { Yes - carbide section } \\
\text { No-HSS }\end{array}$ \\
\hline 4. Fail safes & No & Yes - poka yoke \\
\hline 5. Reduced inventory & $\begin{array}{l}\text { No - high raw materials, } \\
\text { WIP and finished product }\end{array}$ & $\begin{array}{l}\text { Yes }- \text { of raw materials } \\
\text { No - consumables not JIT }\end{array}$ \\
\hline \multicolumn{3}{|c|}{ Manufacturing, planning and control } \\
\hline 1. Visual systems & No & Yes \\
\hline 2. Pull systems & No & Yes \\
\hline $\begin{array}{l}\text { 3. Level loading and } \\
\text { reduced bottlenecks or } \\
\text { WIP }\end{array}$ & $\begin{array}{l}\text { No - result of variable } \\
\text { items per shot }\end{array}$ & $\begin{array}{l}\text { No-balanced workloads } \\
\text { in carbide but high WIP in } \\
\text { HSS }\end{array}$ \\
\hline $\begin{array}{l}\text { 4. Layout for process flow } \\
\text { and flexibility }\end{array}$ & $\begin{array}{l}\text { No-assemblers located } \\
\text { away, results in } \\
\text { unnecessary transport }\end{array}$ & Yes - reconfigurable \\
\hline \multicolumn{3}{|l|}{ TQM } \\
\hline $\begin{array}{l}\text { 1. Continuous } \\
\text { improvement }\end{array}$ & $\begin{array}{l}\text { No-inspection and } \\
\text { rework not built in quality }\end{array}$ & Yes \\
\hline 2. Six sigma & No & Yes \\
\hline 3. Housekeeping, $5 \mathrm{~S}$ 's & $\begin{array}{l}\text { No-for example, old } \\
\text { machines clutter factory } \\
\text { floor }\end{array}$ & Yes \\
\hline 4. TPM & No - breakdown repair & $\begin{array}{l}\text { Yes - preventative } \\
\text { maintenance in carbide, } \\
\text { less effective in HSS }\end{array}$ \\
\hline
\end{tabular}

JIT, just-in-time; PLM, product life cycle management; HSS, high-speed steel; TQM, total quality management; TPM, total productive maintenance; WIP, work-in-process. 
TABLE 5: Summary of organisational culture and personnel elements.

\begin{tabular}{|c|c|c|}
\hline Personnel & Company A & Company B \\
\hline \multicolumn{3}{|c|}{ Employee integration and information flow } \\
\hline 1. Formalised problem solving & No & Yes \\
\hline 2. Feedback to employees & No & $\begin{array}{l}\text { Good, product performance } \\
\text { feedback }\end{array}$ \\
\hline 3. High level of transparency & No & Yes \\
\hline \multicolumn{3}{|l|}{ Team building } \\
\hline 1. Motivation & Low in factory & High \\
\hline 2. Cross-functional & No & Yes \\
\hline 3. Job rotation & No & Yes \\
\hline \multicolumn{3}{|l|}{ Learning organisation } \\
\hline 1. Continuous improvement & No & Kaizen meetings \\
\hline 2. Change management & No & Yes \\
\hline 3. Training and retraining & Yes & Yes \\
\hline \multicolumn{3}{|c|}{ Employee welfare and satisfaction issues } \\
\hline 1. Disciplinary action & Frequent & Infrequent \\
\hline 2. Health and safety & Good & Good \\
\hline 3. Absenteeism & High & Low \\
\hline 4. Compensation related & Numerous & Seldom \\
\hline 5. Promotion opportunities & Limited & Limited \\
\hline 6. Incentives & No & Yes - for innovative ideas \\
\hline
\end{tabular}

TABLE 6: Summary of customer relationship management in the two companies.

\begin{tabular}{|c|c|c|}
\hline Customer & Company A & Company B \\
\hline \multicolumn{3}{|l|}{ Quality } \\
\hline $\begin{array}{l}\text { 1. Management of } \\
\text { returns }\end{array}$ & $\begin{array}{l}\text { Frequent because of delay, } \\
\text { dealt with on an ad hoc basis }\end{array}$ & $\begin{array}{l}\text { Occasional - quality- } \\
\text { related problems }\end{array}$ \\
\hline $\begin{array}{l}\text { 2. Communication } \\
\text { channels }\end{array}$ & Via salespeople & $\begin{array}{l}\text { Advanced technical } \\
\text { support provided }\end{array}$ \\
\hline \multicolumn{3}{|l|}{ Timeliness } \\
\hline 1. Order cycle time & Short & Short \\
\hline 2. Waiting time & Poor - stockouts frequent & Poor-stockouts frequent \\
\hline 3. Speed of delivery & Good if available, 3PL used & Good, 3PL, <24 h \\
\hline \multicolumn{3}{|l|}{ Flexibility } \\
\hline $\begin{array}{l}\text { 1. Emergency order } \\
\text { procedures }\end{array}$ & Responsive if stock available & $\begin{array}{l}\text { Responsive if stock } \\
\text { available }\end{array}$ \\
\hline 2. Choice of lot size & No & No \\
\hline 3. Variety & $\begin{array}{l}\text { High but being decreased to } \\
\text { improve availability }\end{array}$ & High \\
\hline 4. Customisation & $\begin{array}{l}\text { Subject to extended } \\
\text { lead times }\end{array}$ & $\begin{array}{l}\text { Make-to-order 4-week } \\
\text { delay }\end{array}$ \\
\hline \multicolumn{3}{|l|}{ Value } \\
\hline $\begin{array}{l}\text { Customer needs } \\
\text { assessment }\end{array}$ & $\begin{array}{l}\text { Not formal, but salespeople } \\
\text { involved in NPD } \\
\text { Long-term customers enjoy } \\
\text { preferential treatment }\end{array}$ & $\begin{array}{l}\text { Technical support and } \\
\text { after-sales service }\end{array}$ \\
\hline
\end{tabular}

NPD, new product development.

Company B's finished inventory levels are high in the carbide factory because of economic batch quantity (EBQ) constraints associated with international customers, but the feasibility of a make-to-order strategy was being assessed. In this section, batch size has been reduced and a reconfigurable layout has added flexibility. Work cells improve efficiency. Finished inventory levels are high in the HSS factory because of overproduction. This section of the plant has a more rigid layout with ageing machinery and longer setup times.

\section{Personnel and organisational culture}

Very different organisational cultures were encountered in the two companies. Table 5 shows the elements of personnel and organisational culture that were particularly relevant to lean operations.
TABLE 7: Summary of agile capability of the two companies.

\begin{tabular}{lll}
\hline Supply chain aspect & Company A & Company B \\
\hline Supplier relationships & Little evidence & Little evidence \\
Operations & Little evidence & Yes \\
Organisational culture and personnel & Little evidence & Yes \\
Customer relations & Agile in some areas & Agile in some areas \\
\hline
\end{tabular}

Overall, Company A's management appeared to experience an antagonistic relationship with its factory employees, although with office staff there was a far more collaborative culture.

Company B was successfully introducing lean human resources practices such as kaizen meetings. Responsibilities were devolved to lower levels and incentives encourage employees to be innovative.

\section{Customer relations}

The aspects of customer relationship management relevant to lean operations are summarised in Table 6. Company B was found to have a better developed customer relationship management system than Company A in terms of aftersales service and customer feedback. It experienced fewer returns, but a concern was that these were mainly for quality reasons. There was little evidence of customisation in either company, and the willingness to make-to-order appeared to be compromised as a result of extended production lead times.

Communication through sales people was good for Company A, but the returns they experienced were mostly because of delays in filling orders and rejection by customers as a result.

\section{Potential for agility}

The markets for products produced by companies A and B exhibit volatility, with fluctuations in both variety of product demanded by the customers and volumes needed. The catalogues of both companies offer considerable variety, but demand for the different items is not consistent. Both companies experience stockouts and long lead times to supply out-of-stock products. In spite of good communication with customers, they are unable to respond rapidly and flexibly to demand. Many of their products are highly differentiated and may experience short life cycles.

This suggests the need for continual future product design changes and process requirement changes. Both companies need to increase their agility to service their markets better.

The agile capabilities of Companies A and B were compared, and an assessment of their performance with regard to the four key aspects of the supply chain is summarised in Table 7. Neither company had an effective supplier relationship, with systems such as fluid collaborations, vendor managed inventory (VMI), outsourcing or effective communication to 
facilitate speed, flexibility and response in supply. Company $\mathrm{A}$ is not well equipped to produce greater variety, with long setup times, an inflexible layout and a low investment in technology. Furthermore, their organisational culture does not encourage agility because the workforce is not empowered to be self-managed or motivated. Company B, however, has already developed a flexible, proactive workforce. Their carbide section is technologically advanced and setup times are short. Both companies are performing well in some aspects of their customer relationships and poorly in others. The 3PL companies allow them to deliver with a short lead time, but only on products that are already in finished goods inventory. Lead times are excessive for products on their catalogue which they do not have in stock. Forecasting is weak, and communication with customers to anticipate demand is poor. Nonetheless, relationships appear to be good as a result of good after-sales service and motivated sales teams.

\section{Discussion}

The framework developed for this study provided a comprehensive approach for assessing lean capabilities. The different themes that were identified were easily understood by respondents and highlighted areas of strength and areas of weakness within each company.

Company B has a significantly leaner operation than Company A. It has reduced inventory, setup time and increased flexibility. Another key difference between the two companies is in their organisational culture. Company B has embraced the lean principles of team work, devolution of responsibility and open information flows. Company A experiences an antagonistic relationship between shop floor and management. This obstacle suggests that it will be difficult to succeed with lean. Investments in improved technologies, and information systems in particular, may assist in improving human resources efficiency.

Neither company has achieved lean supply management. The literature suggests that this is a particular challenge for SMEs, which do not carry the financial weight to influence suppliers. Company B has had some success in establishing a JIT supply with local partners and has developed some strategic alliances, but imported raw materials pose a major challenge.

Although both companies are facing uncertain market environments, both are still profitable and offer products that usually meet customer requirements. There are weaknesses in their ability to meet changes in demand and to supply the variety of products needed.

In terms of agility readiness, the introduction of lean has given Company $\mathrm{B}$ an advantage. Some of the IT and automation capabilities are in place, and the workforce is flexible and motivated to improve performance. It seems most unlikely that Company A could achieve agility without first improving these same aspects of their operation. The findings support the contention that lean serves as an important precursor to agile. Furthermore, there is no indication that lean is compromising agility or resulting in rigid practices that reduce responsiveness. It may be that an incomplete implementation of lean is important: A fully realised lean system may in practice restrict a firm's agility, but preliminary steps taken on the lean journey may enable the development of the agile capabilities of the supply chain. Small organisations, by their very nature, may already be more adaptable and responsive. If they can achieve responsiveness to customer needs by efficient and flexible operations, they may not need to contradict the principles of lean by holding excessive inventory. The key to improving both the lean and agile capabilities may lie in taking full advantage of modern communications technology to develop more effective and versatile collaborations with customers, suppliers and competitors. Small- and medium-sized enterprises could support a virtual supply chain that has the agility to meet and exceed customer expectations.

Although the findings are not necessarily generalisable to the wider population of SMEs, because the sample was limited to two companies, several avenues for further investigation were suggested by this study. The framework that was developed provides a useful tool to structure assessments of lean and agile capabilities in SMEs. From the findings of this exploratory study, a 'Lean to Agile Journey' is proposed. This journey will take companies from a traditional, mass production strategy to agility through a sequenced implementation of lean principles and practices. This staged approach is illustrated in Figure 2.

Waste reduction, through the use of lean operating practices, should be accompanied by any organisational culture changes that are needed to develop a self-managed and empowered work force.

Once the company in focus is lean, it should turn its attention to suppliers and customers and initiate the process of supply chain integration. Improving relationships and information flow is critical in achieving a lean supply chain. Just-in-time is only possible once these relationships are well developed. Six Sigma and Taguchi methods can elevate the focal company's operations to an even higher level, with reduced costs and improved quality.

Finally, the lean company is in a position to reassess its agility and to make the necessary adjustments to achieve speed, flexibility and response. This requires the development of a virtual supply chain which can be reconfigured to meet volatile demand. A network of SMEs which collaborates to produce a wide variety of products and achieves the critical mass to overcome international supply constraints may prove more agile than larger competitors. 


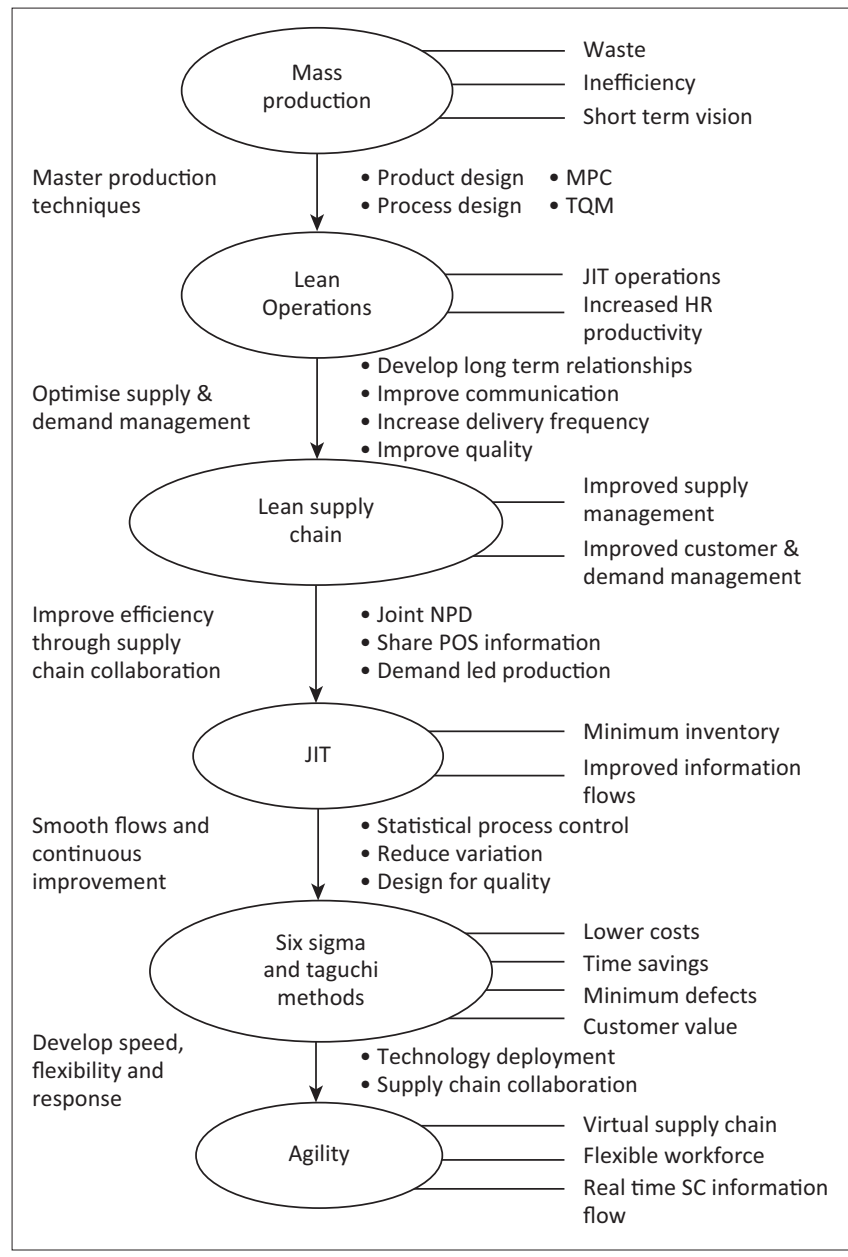

TQM, total quality management; JIT, just-in-time; NPD, new product development; MPC, manufacturing planning and control; SC, supply chain.

FIGURE 2: The lean journey for small- and medium-sized enterprises.

\section{Acknowledgements}

The authors would like to thank the companies for allowing them access to their operations.

\section{Competing interests}

The authors declare that they have no competing interests with regard to the writing of this article.

\section{Authors' contributions}

N.G. conducted empirical research leading to the awarding of a Master of Commerce degree in supply chain management. Data collected towards fulfilling this degree were used in the preparation of this article. R.H.S. supervised the research conducted by N.G., and using some of the data from this research, determined and wrote the content of this article.

\section{References}

Abor, J. \& Quartey, P., 2010, 'Issues in SME development in Ghana and South Africa', International Research Journal of Finance and Economics 39(6), 215-228.

Achanga, P., Shehab, E., Roy, R. \& Nelder, G., 2006, 'Critical success factors for lean implementation within SMEs', Journal of Manufacturing Technology Management 17(4), 460-471. https://doi.org/10.1108/17410380610662889
Bortolotti, T., Romano, P., Martínez-Jurado, P.J. \& Moyano-Fuentes, J., 2016, 'Towards a theory for lean implementation in supply networks', International Journal of Production Economics 175, 182-196. https://doi.org/10.1016/j.ijpe.2016.02.020

Bottani, E., 2010, 'Profile and enablers of agile companies: An empirical investigation' International Journal of Production Economics 125(2), 251-261. https://doi.org/ 10.1016/j.ijpe.2010.02.016

Boyce, C. \& Neale, P., 2006, Conducting in-depth interviews: A guide for designing and conducting in-depth interviews for evaluation input, viewed 30 August 2014, from http://www.pathfinder.org/publications-tools/Conducting-In-Depth-InterviewsA-Guide-for-Designing-and-Conducting-In-Depth-Interviews-for-EvaluationInput.html:http://www. pathfinder.org/publications-tools/Conducting-In-DepthInterviews-A-Guide-for-Designing-and-Conducting-In-Depth-Interviews-forEvaluation-Input.html

Bruce, M., Daly, L. \& Towers, N., 2004, 'Lean or agile: A solution for supply chain management in the textiles and clothing industry?', International Journal of Operations \& Production Management 24(2), 151-170. https://doi.org/10.1108/ 01443570410514867

Cao, Q. \& Dowlatshahi, S., 2005, 'The impact of alignment between virtual enterprise and information technology on business performance in an agile manufacturing environment', Journal of Operations Management 23(5), 531-550. https://doi. org/10.1016/j.jom.2004.10.010

Chong, M.Y., Chin, J.F. \& Loh, W.P., 2013, 'Lean incipience spiral model for small and medium enterprises', International Journal of Industrial Engineering 20, 487-501.

Christopher, M., 2000, 'The agile supply chain: Competing in volatile markets', Industrial Marketing Management 29(1), 37-44. https://doi.org/10.1016/S00198501(99)00110-8

Christopher, M. \& Towill, D.R., 2000, 'Supply chain migration from lean and functional to agile and customised', Supply Chain Management: An International Journal 5(4), 206-213. https://doi.org/10.1108/13598540010347334

Chung, W.W.C. \& Chan, M.F.S., 2001, 'Role of IT/IS in physically distributed manufacturing enterprises', in A. Gunasekaran (ed.), Agile manufacturing - The 21st Century Competitive Strategy, pp. 601-620, Elsevier, Oxford.

Dahlgaard, J.J. \& Dahlgaard-Park, S.M., 2006, 'Lean production, six sigma quality, TQM and company culture', The TQM Magazine 18(3), 263-281. https://doi. org/10.1108/09544780610659998

Duguay, C.R., Landry, S. \& Pasin, F., 1997, 'From mass production to flexible/agile production', International Journal of Operations \& Production Management 17(12), 1183-1195. https://doi.org/10.1108/01443579710182936

Fening, F.A., Pesakovic, G. \& Amaria, P., 2008, 'Relationship between quality management practices and the performance of small and medium size enterprises (SMEs) in Ghana', International Journal of Quality \& Reliability Management 25(7), 694-708. https://doi.org/10.1108/02656710810890881

Fornasiero, R. \& Zangiacomi, A., 2013, 'A structured approach for customised production in SME collaborative networks', International Journal of Production Research 51(7), 2110-2122. https://doi.org/10.1080/00207543.2012.706718

Gunasekaran, A., 1999, 'Agile manufacturing: A framework for research and development', International Journal of Production Economics 62(1-2), 87-105. https://doi.org/10.1016/S0925-5273(98)00222-9

Gunasekaran, A., McGaughey, R. \& Wolstencroft, V., 2001, 'Agile manufacturing Concepts and framework', in A. Gunasekaran (ed.), Agile manufacturing - The 21st Century Competitive Strategy, pp. 25-49, Elsevier, Oxford.

Gunasekaran, A. \& Yusuf, Y.Y., 2002, 'Agile manufacturing: A taxonomy of strategic and technological imperatives', International Journal of Production Research 40(6), 1357-1385. https://doi.org/10.1080/00207540110118370

Hu, Q., Mason, R., Williams, S.J. \& Found, P., 2015, 'Lean implementation within SMEs: A literature review', Journal of Manufacturing Technology Management 26(7), 980-1012. https://doi.org/10.1108/JMTM-02-2014-0013

Inman, R.A., Sale, R.S., Green, K.W. Jr. \& Whitten, D., 2011, 'Agile manufacturing Relation to JIT, operational performance and firm performance', Journal of Operations Management 29(4), 343-355. https://doi.org/10.1016/j.jom.2010. 06.001

Jin-Hai, L., Anderson, A.R. \& Harrison, R.T., 2003, 'The evolution of agile manufacturing' Business Process Management Journal 9(2), 170-189. https://doi.org/10.1108/ 14637150310468380

Ketokivi, M. \& Choi, T., 2014, 'Renaissance of case research as a scientific method', Journal of Operations Management 32(5), 232-240. https://doi.org/10.1016/j. jom.2014.03.004

Lamming, R., 2005, 'Supplier Relationship Management', in M. EßIG (ed.), Perspektiven des supply management: Konzepte und Anwendungen, pp. 81-94, Springer, Berlin.

Mason-Jones, R., Naylor, B. \& Towill, D.R., 2000, 'Lean, agile or leagile? Matching your supply chain to the marketplace', International Journal of Production Research 38(17), 4061-4070. https://doi.org/10.1080/00207540050204920

Monden, Y., 1983, Toyota production system: A practical approach to production management, Institute of Industrial Engineers, Atlanta, GA.

Naim, M.M. \& Gosling, J., 2011, 'On leanness, agility and leagile supply chains', International Journal of Production Economics 131(1), 342-354. https://doi.org/ 10.1016/j.ijpe.2010.04.045

Naylor, J.B., Naim, M.M. \& Berry, D., 1999, 'Leagility: Integrating the lean and agile manufacturing paradigms in the total supply chain', International Journal of Production Economics 62(1), 107-118. https://doi.org/10.1016/S0925-5273(98) 00223-0

Nel, J. \& Badenhorst-Weiss, J., 2012, 'Using a theoretical road map for the management of lean supply chains', Journal of Contemporary Management 9, 190-211. 
Pandey, V. \& Garg, S., 2009, 'Analysis of interaction among the enablers of agility in supply chain', Journal of Advances in Management Research 6(1), 99-114. https:// doi.org/10.1108/09727980910972190

Panizzolo, R., Garengo, P., Sharma, M.K. \& Gore, A., 2012, 'Lean manufacturing in developing countries: Evidence from Indian SMEs', Production Planning \& Control 23(10-11), 769-788. https://doi.org/10.1080/09537287.2011.642155

Power, D.J., Sohal, A.S. \& Rahman, S.U., 2001, 'Critical success factors in agile supply chain management - An empirical study', International Journal of Physical Distribution \& Logistics Management 31(4), 247-265. https://doi.org/10.1108/ 09600030110394923

Purvis, L., Gosling, J. \& Naim, M.M., 2014, 'The development of a lean, agile and leagile supply network taxonomy based on differing types of flexibility, International Journal of Production Economics 151, 100-111. https://doi.org/ 10.1016/j.ijpe.2014.02.002

Reichhart, A. \& Holweg, M., 2007, 'Lean distribution: Concepts, contributions, conflicts', International Journal of Production Research 45(16), 3699-3722. https://doi.org/10.1080/00207540701223576

Shah, R. \& Ward, P.T., 2003, 'Lean manufacturing: Context, practice bundles, and performance', Journal of Operations Management 21(2), 129-149. https://doi. org/10.1016/S0272-6963(02)00108-0
Van Hoek, R.I., Harrison, A. \& Christopher, M., 2001, 'Measuring agile capabilities in the supply chain', International Journal of Operations \& Production Management 21(1/2), 126-148. https://doi.org/10.1108/01443570110358495

Womack, J.P. \& Jones, D.T., 2003, Lean thinking - Banish waste and create wealth in your corporation, Free Press, New York.

Womack, J.P., Jones, D.T. \& Roos, D., 1990, The machine that changed the world, Rawson Associates, New York.

Yin, R.K., 2003, Case study research: Design and methods, Sage, Thousand Oaks, CA.

Yusuf, Y.Y., Gunasekaran, A., Musa, A., Dauda, M., El-Berishy, N.M. \& Cang, S., 2014 'A relational study of supply chain agility, competitiveness and business performance in the oil and gas industry', International Journal of Production Economics 147(Part B), 531-543. https://doi.org/10.1016/S0925-5273(98) 00219-9

Yusuf, Y.Y., Sarhadi, M. \& Gunasekaran, A., 1999, 'Agile manufacturing: The drivers, concepts and attributes', International Journal of Production Economics 62(1/2), 33-43.

Zhang, D.Z., 2011, 'Towards theory building in agile manufacturing strategies - Case studies of an agility taxonomy', International Journal of Production Economics 131(1), 303-312. https://doi.org/10.1016/j.ijpe.2010.08.010 